\title{
Regional characteristics of Arctic temperature variability: comparison of observations with regional climate simulations
}

\author{
A. Rinke* ${ }^{*}$ H. Matthes, K. Dethloff \\ Alfred Wegener Institute for Polar and Marine Research, Telegrafenberg A43, 14473 Potsdam, Germany
}

\begin{abstract}
Regional-scale interannual variability of the seasonal air temperature and the intraseasonal extreme temperature range and their seasonality were investigated for the pan-Arctic and also (in more detail) for Russian Arctic land. Daily mean, minimum, and maximum temperatures were obtained from the 'Global Summary of Day' station data set for the period 1958 to 2008 (51 yr) and from the gridded data of the ERA40 reanalysis and regional climate model HIRHAM simulations for the period 1958 to 2001 (44 yr). Because of a high degree of variability in both temperatures and temperature extremes in the analysis period, it was difficult to identify significant trends. The trends in seasonal temperatures were positive overall, but not significant for the western Russian Arctic. A significant warming in the seasonal temperature was confirmed for the eastern Russian Arctic $\left(0.4\right.$ to $0.9^{\circ} \mathrm{C}$ decade ${ }^{-1}$, depending on the season, in the $51 \mathrm{yr}$ station record). Generally, the trends in the seasonal extreme temperature range were of mixed sign and were not statistically significant for the longer record, except for the negative trend of $-0.3^{\circ} \mathrm{C}$ decade ${ }^{-1}$ for the eastern Russian Arctic in summer. The interannual variability of both temperature measures in turn showed a pronounced decadal variability and considerable regional and seasonal characteristics. The HIRHAM model reproduced the observed temporal evolution and magnitude of the observed temperature variability reasonably well.
\end{abstract}

KEY WORDS: Arctic climate Climate variability ' Regional climate model Temperature . Russian Arctic

\section{INTRODUCTION}

While it is well established that the Arctic is a region that is particularly sensitive to climate change (e.g. Serreze \& Francis 2006) the region is nevertheless characterized by a high degree of variability (e.g. in the observed surface air temperature), and this has been particularly so over the 20th century (e.g. Overland et al. 2004, Matthes et al. 2009). Climate models need to reproduce this past and present climate variability so that their results can be used with confidence for 21st century projections.

The spatial patterns of Arctic temperature anomalies do not necessarily always project strongly on the 2 main climate patterns, the Arctic Oscillation and Paci- fic North America Patterns, and are also associated with feedbacks within the Arctic (Overland et al. 2004). The latter is particularly important for regionalscale variability, but there is a lack of research on this for the Arctic region. Recently, Alexander et al. (2006) provided a comprehensive global analysis of observed changes in climate indices derived from daily temperatures. However, the examined stations were primarily located in North America (most of them on the mainland), Eurasia (only very few of them in the Arctic region), and Australia. Arctic-specific studies include those of Przybylak (2002), who studied 10 stations representing the major Arctic climate regions, and Overland et al. (2004), who analyzed 59 stations covering the pan-Arctic. Due to this poor spatial data coverage 
in the Arctic, all earlier studies do not allow us to assess the considerable regional-scale temperature variability that can be simulated by regional climate models (RCMs). Hence, our approach here was to analyze data from a relatively dense station network over Russian Arctic land, as well as from high-resolution Arctic RCM simulations that provide the opportunity to quantify the regional-scale climate variability. The regional focus of this paper is on the Russian Arctic and has its background in the EU project CARBO-North (www. carbonorth.net/), which aims at quantifying the carbon budget in northern Russia.

Here we examined the high-resolution spatial and temporal differences in the interannual variability of seasonal temperatures and the range of temperature extremes over the pan-Arctic and in more detail over the Russian Arctic. The objectives were to document the spatial patterns of this variability and to supply information on variability and change in the seasonal temperature and the intra-seasonal range of temperature extremes, based on observations and reanalyses. Another important aspect was to determine how well the RCM HIRHAM reproduces the observed variability, in order to increase our confidence in future projections.

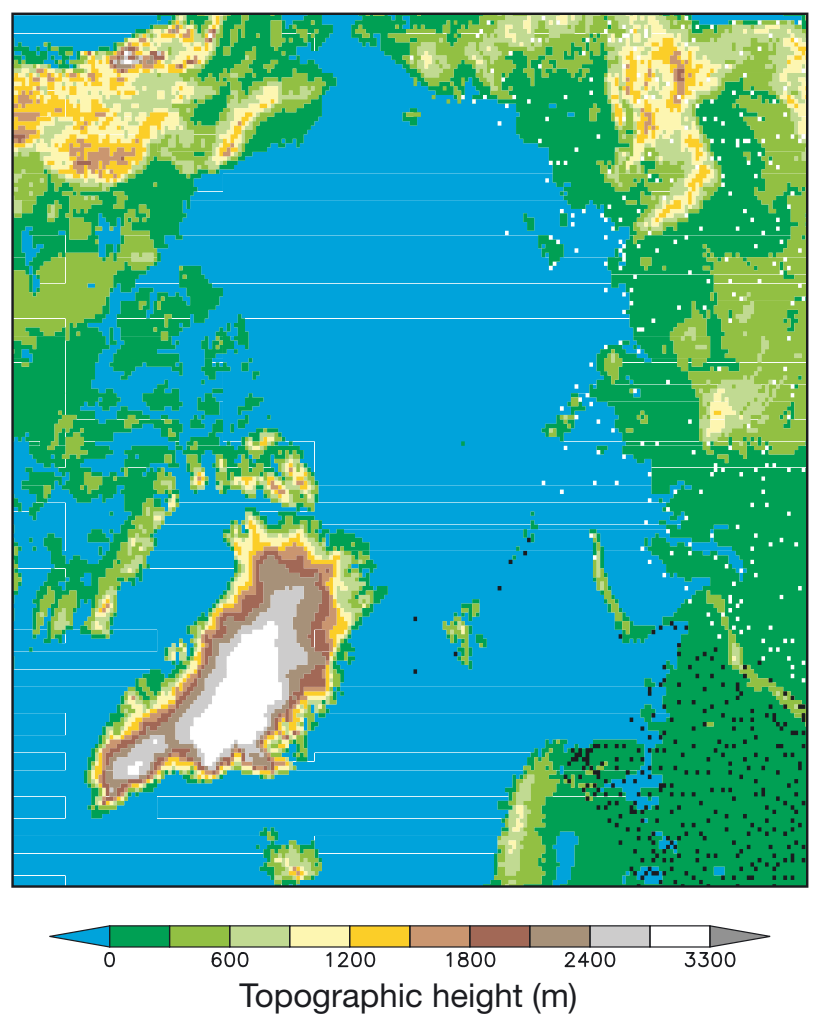

Fig. 1. Station distribution of the Arctic Russian GSOD data set. Grey (black) points show the locations of the 324 (320) stations in the eastern (western) part. Colors according to topographic height $(\mathrm{m})$
Section 2 describes the observational data sets that we examined, the analysis that we performed, and the HIRHAM simulation. The results for the variability of seasonal temperature and the intra-seasonal range of temperature extremes are discussed in Section 3. Section 4 presents a summary and conclusions.

\section{DATA AND SIMULATIONS}

\subsection{Observational data and analysis}

\subsubsection{Data sets}

The 'Global Summary of Day' (GSOD) station data set obtained from the National Climatic Data Center (NCDC) was analyzed for Russian Arctic land. Altogether, daily mean, minimum, and maximum $2 \mathrm{~m}$ air temperature data of 644 stations located in the Russian Arctic north of $60^{\circ} \mathrm{N}$ were compiled for the period 1958 to 2008 . The data were separated into 2 parts, GSOD east (324 stations) and GSOD west (320 stations), with stations located east and west of the Urals, respectively (Fig. 1). Using this approach, we were able to perform a regional analysis for the 2 climatologically different regions of the Russian Arctic. GSOD east represents the eastern and central parts of the Russian Arctic, which have a high degree of continentality and are characterized mainly by anticyclones, while GSOD west represents the western Russian Arctic, which is under strong control of North Atlantic cyclones and is influenced by the NAO.

We also analyzed the 4 times daily gridded panArctic $2 \mathrm{~m}$ air temperature data set from the European Centre for Medium-Range Weather Forecasts (ECWMF) re-analysis (ERA40; Uppala et al. 2005) for the time period 1958 to 2001 . These data are at $1.125^{\circ}$ horizontal resolution. For comparison to the station data, the ERA40 data were interpolated on the station locations, using a linear interpolation from the 4 grid points surrounding the station.

\subsubsection{Analyzed fields}

From the daily mean temperatures, seasonal mean data were calculated. Data of a station were included in the analysis of a season if the station had $\leq 10$ missing values within that season. Times series presented here show a station mean for a specific season, if $\geq 10 \%$ of the stations delivered data for that season. This way, the seasonal mean $2 \mathrm{~m}$ air temperature, averaged over 1958 to 2001 (2008) was evaluated.

The interannual temperature variability (ITV) for each season, based on the gridded data, was computed 
as the standard deviations (SDs) of the 44 (51) seasonal means, 1 for each year of 1958 to 2001 (2008). To examine the temporal ITV variation within the analyzed time periods, based on the station data, the SDs relative to $11 \mathrm{yr}$ running means were calculated and included in the time series figures (and assigned to the center of the $11 \mathrm{yr}$ windows). SDs were calculated if $\geq 6$ of the years within the $11 \mathrm{yr}$ window had data.

The intra-seasonal extreme temperature range (ETR; defined as the hottest daily maximum temperature in the season minus the coldest daily minimum temperature in the season) was also analyzed. ETR is a simple but a useful measure of the extreme temperature variability.

\subsubsection{Statistical methods}

Basically, 2 methods of data analysis were used to quantify the variability of the temperature by analyzing the measures of ITV and ETR.

(1) Time series for the eastern and western parts of the Russian Arctic (GSOD east and west) were generated in order to evaluate spatially averaged time series for the 2 climatologically different regions. These time series were compiled for all 3 data sources (GSOD, ERA40, HIRHAM). Trends were calculated using a linear regression with the least squares method. To identify the significance of the trends, a bootstrapping approach as described by Kiktev et al. (2003) was applied, and trends were considered significant at the $95 \%$ level.

(2) To investigate the spatial variation within the pan-Arctic, the spatial patterns of the analyzed variables were examined using the gridded data of ERA40 and HIRHAM. Here we also discuss inter-period differences. For this, the averages over each of two $22 \mathrm{yr}$ periods (1958 to 1979 and 1980 to 2001) were compared to estimate the changes in the mean spatial patterns. The statistical significance of the difference between the 2 periods was identified by means of a $t$ test, and significance was defined at the $95 \%$ level.

\subsection{Model and simulations}

The RCM employed in this study was the HIRHAM model (Dethloff et al. 1996), which has been applied in a wide range of Arctic climate studies (e.g. recently by Rinke et al. 2008, 2009). The physical parameterizations in the model were those from ECHAM4 (Roeckner et al. 1996), except that the ECHAM4 land surface scheme was replaced by the more advanced LSM scheme (Saha et al. 2006). For our study, the HIRHAM model was applied on a pan-Arctic domain that covers the area north of $\sim 60^{\circ} \mathrm{N}$ (Fig. 1), and was configured at a $0.25^{\circ}(\sim 25 \mathrm{~km})$ horizontal resolution and with 19 vertical levels. At the ocean lower boundary, the model was forced by sea surface temperature and sea ice fraction from ERA40 (updated daily); sea ice thickness was prescribed to $2 \mathrm{~m}$. The sea ice surface temperature was calculated prognostically via a heat balance equation. At its lateral boundaries, HIRHAM was forced by the ERA40 data every $6 \mathrm{~h}$. The simulation was performed over the $44 \mathrm{yr}$ from 1958 to 2001.

For comparison to the station data, the HIRHAM data were interpolated to the station locations. To compare HIRHAM to the ERA40 data, the latter were interpolated onto the HIRHAM grid, and standard error measures like mean bias, root mean square error (RMSE), and pattern correlation coefficient (patcor) were calculated.

\section{RESULTS AND DISCUSSION}

\subsection{Variability and change in seasonal temperature}

Both the HIRHAM simulations and the ERA40 data showed considerable agreement in the magnitudes, spatial patterns, and seasonality of the ITV (Table 1, Fig. 2). A strong seasonality in ITV is obvious, as already indicated by earlier studies (e.g. Przybylak 2002, Chapman \& Walsh 2007). The strongest variability of 3 to $6^{\circ} \mathrm{C}$ was found in winter and transition seasons along the sea ice edges due to the high interannual sea ice variability. In addition, the highest ITV (3 to $6^{\circ} \mathrm{C}$ ) was found in winter over the Barents and Kara Seas, central Russian Arctic land, Baffin Bay, and Alaska. All of these regions are characterized by a large year-to-year variable atmospheric circulation, associated with strong cyclonic activity (e.g. Serreze et al. 1993). In contrast, most of eastern Siberia, northern Canada, and the Arctic Ocean are regions domi-

Table 1. Comparison of seasonal air temperature patterns of the HIRHAM simulation and ERA40 data. Shown are the root mean square error (RMSE, ${ }^{\circ} \mathrm{C}$ ), mean bias 'HIRHAM minus ERA40' (bias, ${ }^{\circ} \mathrm{C}$ ), and pattern correlation coefficient (patcor) for the standard deviation (SD) of 1958 to 2001 and the difference '1980-2001 minus 1958-1979'

\begin{tabular}{|c|c|c|c|c|c|c|}
\hline & \multicolumn{3}{|c|}{$-\mathrm{SD} \longrightarrow$} & \multicolumn{3}{|c|}{$-\mathrm{SD}$ difference } \\
\hline & RMSE & bias & patcor & RMSE & bias & patcor \\
\hline Winter & 0.37 & 0.12 & 0.92 & 0.32 & -0.01 & 0.77 \\
\hline Spring & 0.26 & 0.02 & 0.83 & 0.33 & 0.02 & 0.56 \\
\hline Summer & 0.24 & -0.05 & 0.81 & 0.22 & 0.02 & 0.51 \\
\hline Autumn & 0.27 & 0.04 & 0.87 & 0.26 & -0.01 & 0.72 \\
\hline
\end{tabular}



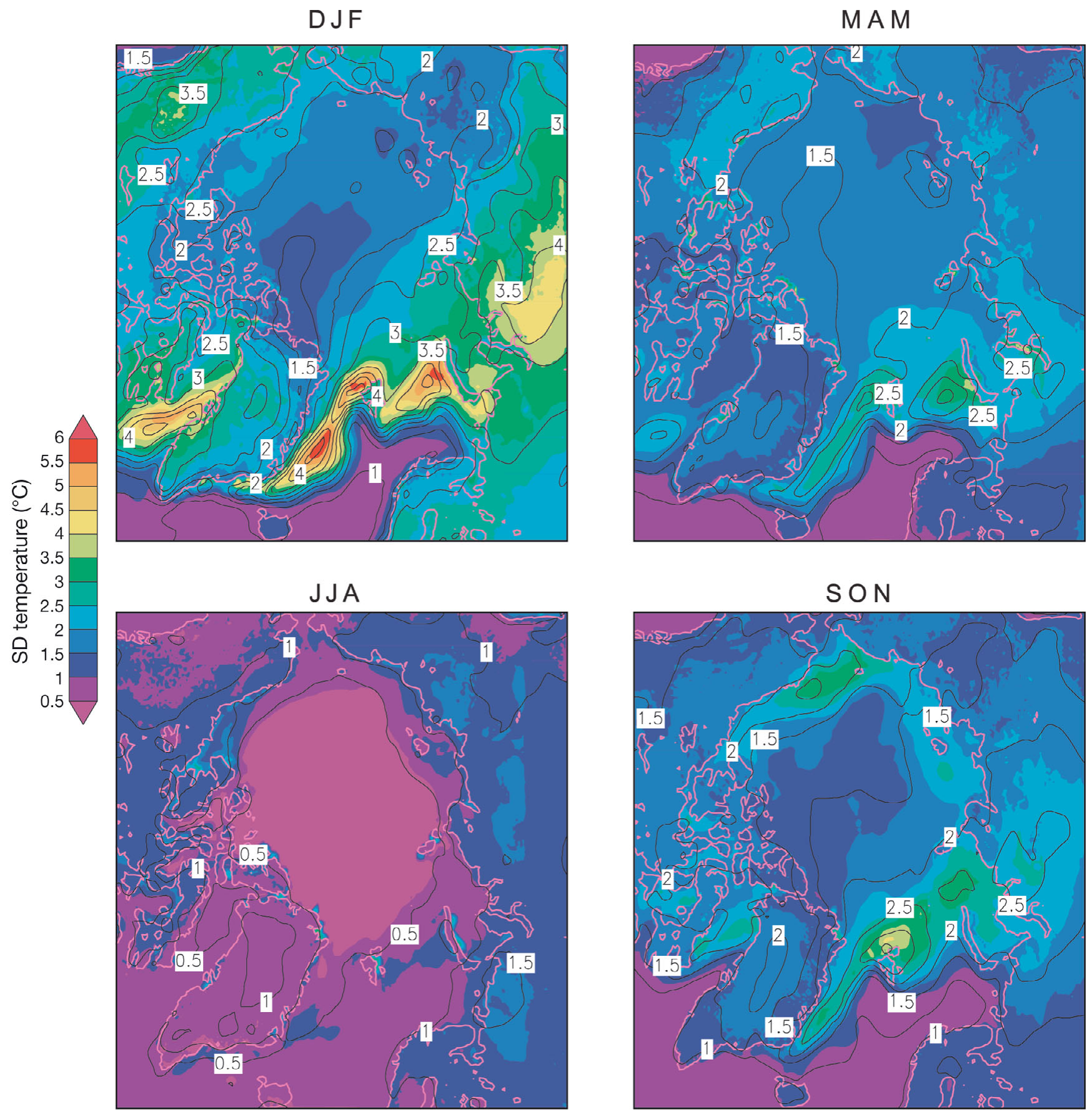

Fig. 2. Seasonal patterns (letters above panels: months) of standard deviation of $2 \mathrm{~m}$ air temperature $\left({ }^{\circ} \mathrm{C}\right), 1958$ to 2001 , based on the HIRHAM simulation (color) and ERA40 data (black isolines; contour interval is $0.5^{\circ} \mathrm{C}$ ). The corresponding comparative measures are given in Table 1. Magenta lines: coastline

nated by anticyclonic activity and thus have a more stable climate. Here, the ITV ranged from 1 to $2.5^{\circ} \mathrm{C}$. The spatial ITV patterns in spring and autumn were similar to those of winter; however, the ITV magnitudes were lower and ranged from 1 to $3.5^{\circ} \mathrm{C}$. ITV was lowest in summer and rarely exceeded $1.5^{\circ} \mathrm{C}$ because of the generally weak atmospheric circulation. The weakest variability $\left(<0.5^{\circ} \mathrm{C}\right)$ was found over sea ice, because melting sea ice constrains the temperature close to the melting point.

HIRHAM generates distinct regional-scale details in ITV due to its 4 -fold higher horizontal resolution com- 

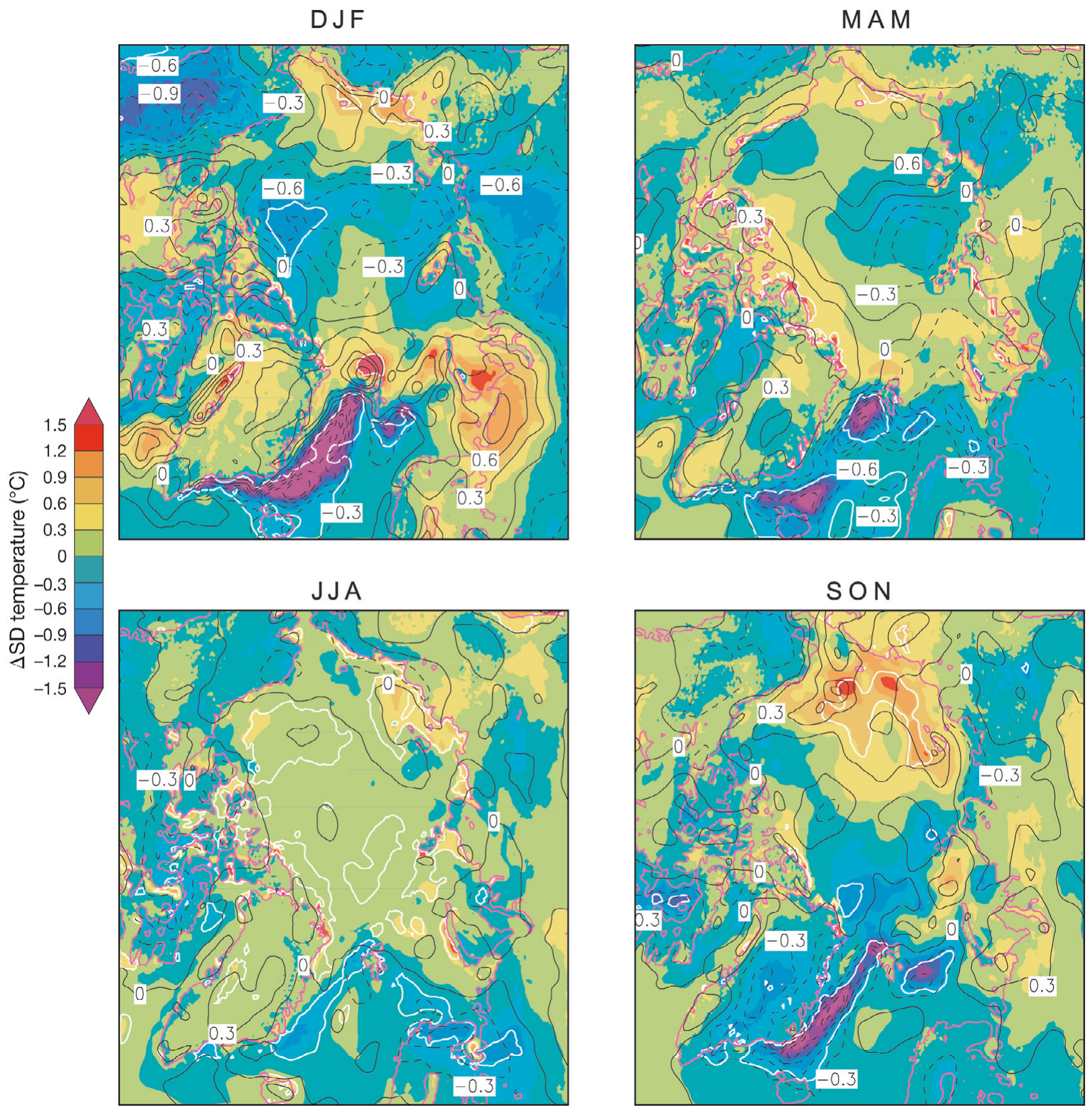

Fig. 3. Seasonal patterns (letters above panels: months) of the difference '1980-2001 minus 1958-1979' of the standard deviation of $2 \mathrm{~m}$ air temperature $\left({ }^{\circ} \mathrm{C}\right.$ ), based on the HIRHAM simulation (color) and ERA40 data (black isolines; contour interval is $0.3^{\circ} \mathrm{C}$; positive [negative] differences are plotted as solid [dashed] isolines). White isolines: significant HIRHAM differences at the $95 \%$ level. The corresponding comparative measures are given in Table 1. Magenta lines: coastline

pared to ERA40. However, the mean spatial ITV patterns of HIRHAM and ERA40 were quite similar (patcor $>0.8$, RMSE $<0.4^{\circ} \mathrm{C}$; see Table 1 ).

To quantify the temporal changes in the spatial ITV patterns, Fig. 3 shows the differences in the seasonal temperature SD between the two 22 yr time periods.
A significant reduction of ITV by 0.5 to $2^{\circ} \mathrm{C}$ was calculated over the northern North Atlantic (particularly over the Greenland Sea) in all 4 seasons for the recent time period. This is associated with the warming and sea ice retreat, such that these earlier ice-edge areas (high ITV) convert to more open ocean regions (low 
Temperature variability $\left({ }^{\circ} \mathrm{C}\right)$

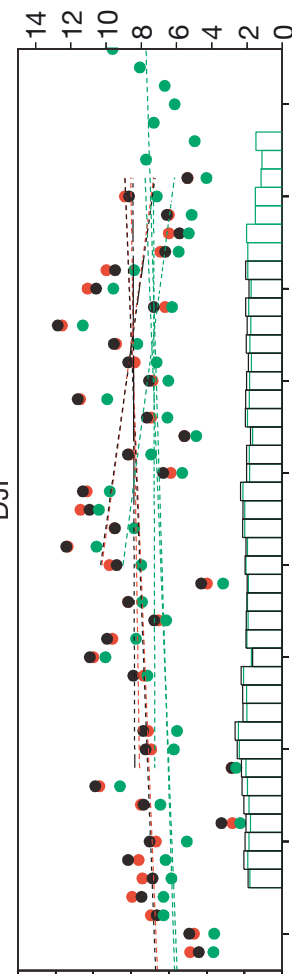

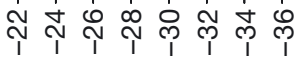
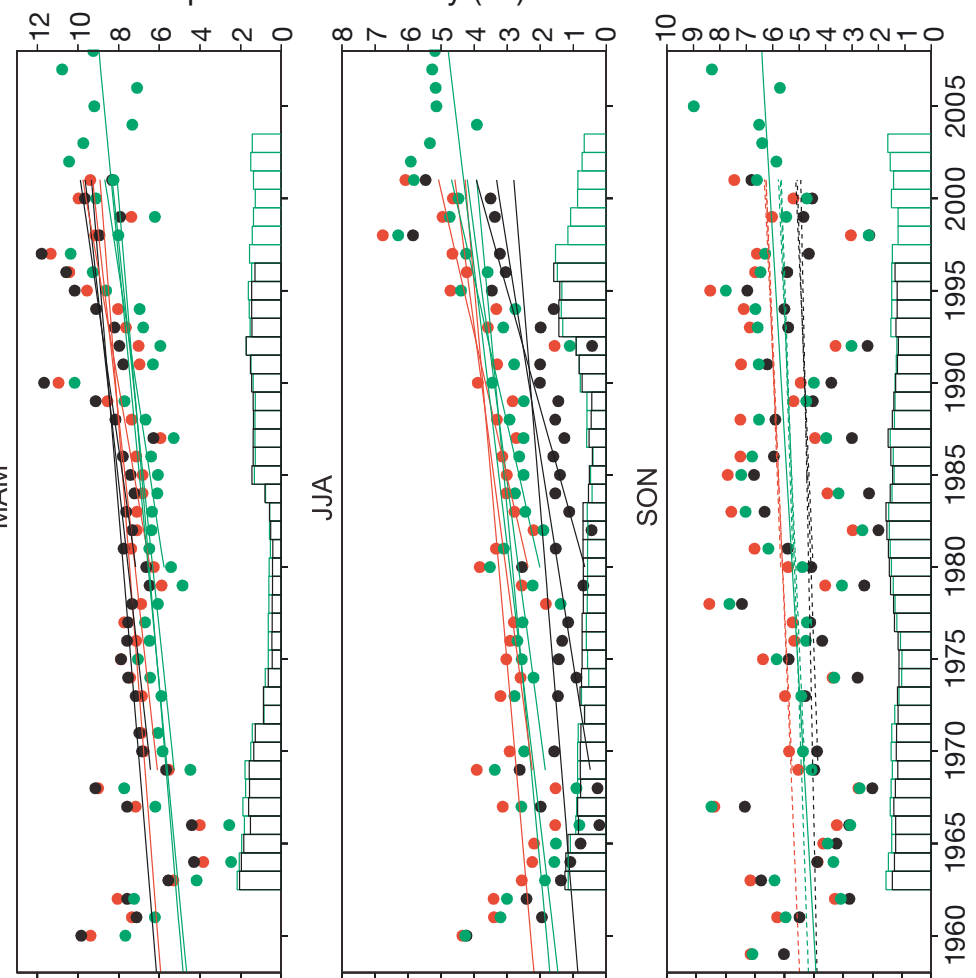

年

LP

Temperature $\left({ }^{\circ} \mathrm{C}\right)$

Temperature variability $\left({ }^{\circ} \mathrm{C}\right)$

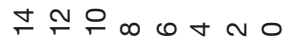

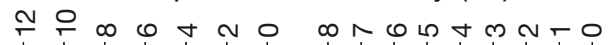

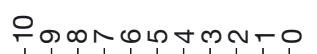
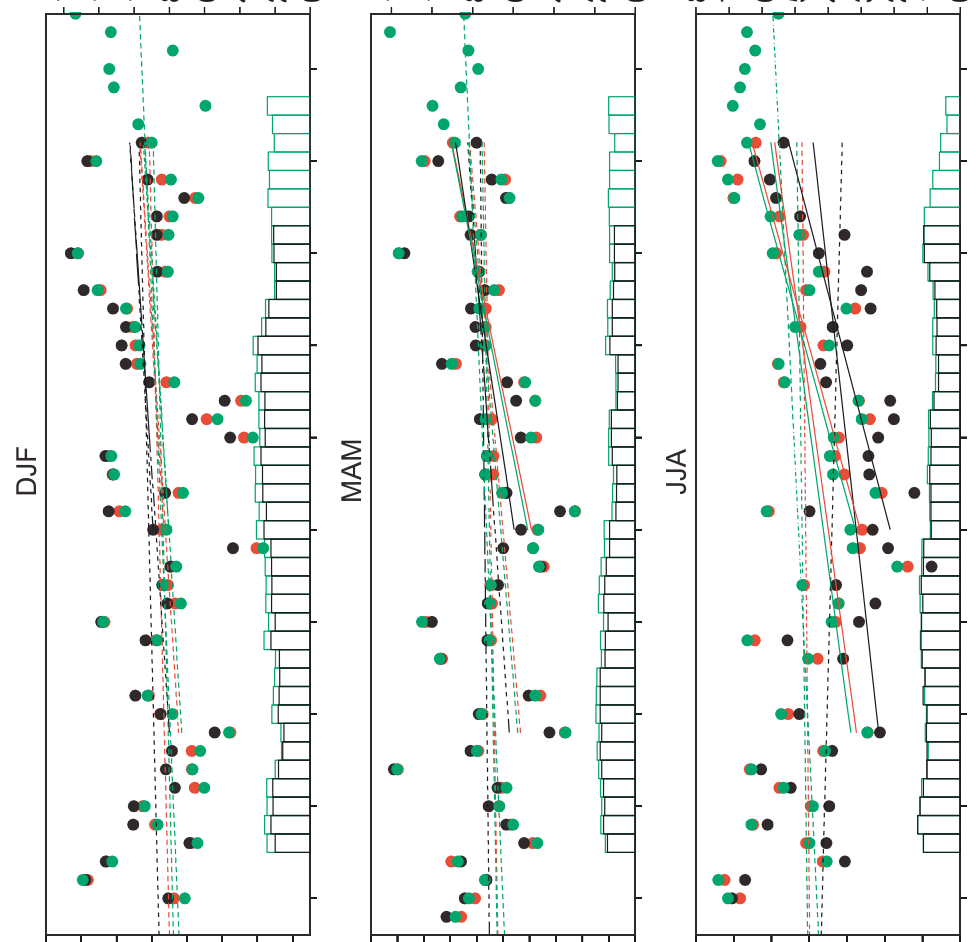

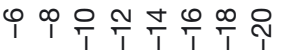

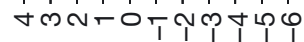

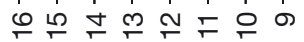
Temperature $\left({ }^{\circ} \mathrm{C}\right)$

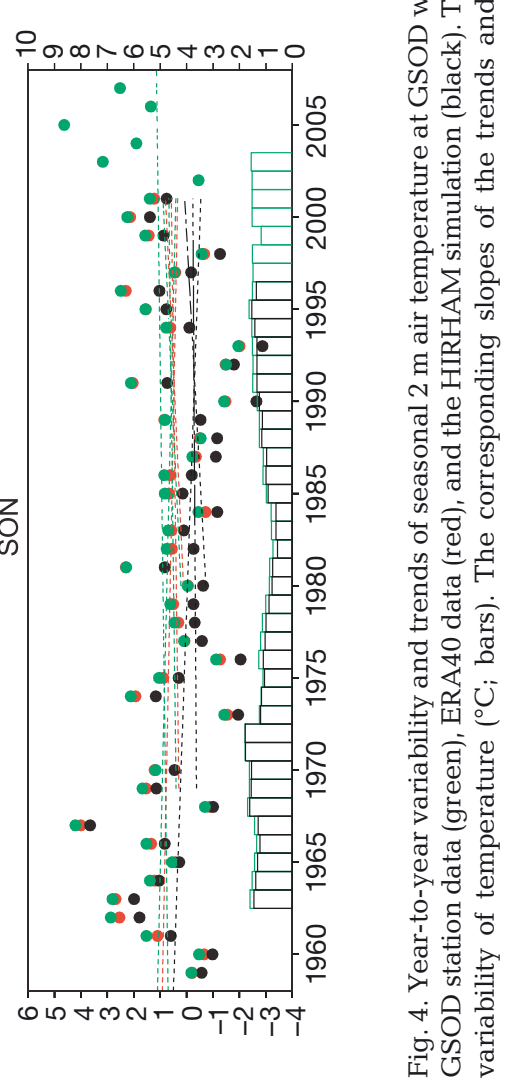


ITV), as seen in the inter-period differences of the sea ice cover (not shown). This ITV reduction is similar to the model projections for future warming scenarios (Rinke \& Dethloff 2008). Another prominent feature was the significant increase of ITV by 0.3 to $1.5^{\circ} \mathrm{C}$ over the Chukchi and East Siberian Seas in the second period in all 4 seasons, particularly in autumn. This is associated with the transformation of these seas from permanently ice-covered (low ITV) in the first period to more frequently ice-free areas characterized by more variable ice coverage (high ITV) in the second period, which is apparent in the interperiod differences of the SD of the ice cover (not shown). Another statistically significant ITV increase appeared over the Kara Sea and north of Svalbard, particularly in winter, associated with the retreating sea ice edges and the increasing trend in the numbers of western Nordic Sea (i.e. Greenland, Iceland and Norwegian Seas) cyclones moving northward (Sorteberg \& Kvingedal 2006). Further, Zhang et al. (2004) showed that Arctic cyclone activity (i.e. storms that bring warm, moist air to the Arctic) increased in number and intensity in the second half of the 20th century, especially in summer, which explains the partly significant increase of ITV over the central Arctic in summer shown in Fig. 3. These dynamicallycaused ITV changes due to the changes in the cyclonic activity were also depicted in the changes in $\mathrm{SD}$ of mean sea level pressure (not shown). Generally, the HIRHAM-simulated patterns of ITV inter-period changes agreed reasonably with those of ERA40, but were more similar in winter and autumn (patcor $=0.7$ to 0.8 ) than in the other 2 seasons (patcor $=0.5$ to 0.6 ; Table 1 ).

Fig. 4 describes the seasonal dependency of temperature and its variability in 2 climatologically different regions of the Russian Arctic in detail. All time series showed a considerable year-toyear temperature variability. The observed maximum limits of variation (difference between the maximum and minimum seasonal mean temperature within the whole $51 \mathrm{yr}$ period) ranged from $5^{\circ} \mathrm{C}$ in summer to $10^{\circ} \mathrm{C}$ in winter. These seasonal limits of variation had the same magnitude in GSOD east and west. Both HIRHAM and ERA40 reproduced this variation in all 4 seasons and in both GSOD east and west well, although HIRHAM systematically underestimated the observed absolute temperature values in summer by about $1^{\circ} \mathrm{C}$. The green bars in Fig. 4, which indicate the observed SDs relative to the 11 yr running means, clearly display the temporal variation of ITV within the complete time series. A distinct decadalscale variability is obvious in all plots, although its characteristics vary with region and season. For both GSOD east and west, the ITV decreased in summertime beginning in the mid-1990s, while in the other seasons, no significant ITV trend in the last decade was visible. For GSOD east, the ITV in spring showed a clear minimum, with values of about $0.5^{\circ} \mathrm{C}$ in the $1970 \mathrm{~s}$ to 1980 s, which is not visible in GSOD west. Further, it must be emphasized that HIRHAM's decadal variation of ITV (black bars in Fig. 4, up to 2001) agreed well with the observed variation.

Table 2 shows the seasonal trends for different time periods, highlighting the general Arctic warming trend since the 1970 s, as recently shown by Chylek et al. (2009). However, it is also obvious that the observed trends over the full $51 \mathrm{yr}$ were not statistically significant for any of the seasons in GSOD west. This corroborates the findings of Jones \& Moberg (2003), who did not identify any significant trends over western Russia. In contrast, for GSOD east, the observed trends were significant and ranged from $0.4^{\circ} \mathrm{C}_{\text {decade }}{ }^{-1}$ in autumn to $0.9^{\circ} \mathrm{C}$ decade $^{-1}$ in spring. No significant trend was found in winter. Further, the observed trends for both GSOD east and west were significantly positive (ca. $1.3^{\circ} \mathrm{C}$ decade $^{-1}$ ) in spring and summer over the second time period 1980 to 2001.

Table 2. Seasonal trends of air temperature $\left({ }^{\circ} \mathrm{C}\right.$ decade $\left.{ }^{-1}\right)$. The values are for station-based (GSOD) and ERA40 data, and for the HIRHAM simulation. ${ }^{*} \mathrm{p}<0.05$

\begin{tabular}{|c|c|c|c|c|c|c|}
\hline & \multicolumn{3}{|c|}{- GSOD west } & \multicolumn{3}{|c|}{- GSOD east } \\
\hline & GSOD & ERA40 & HIRHAM & GSOD & ERA40 & HIRHAM \\
\hline \multicolumn{7}{|c|}{51 yr (1958-2008) } \\
\hline Winter & 0.45 & & & 0.30 & & \\
\hline Spring & 0.31 & & & $0.86^{*}$ & & \\
\hline Summer & 0.24 & & & $0.66^{*}$ & & \\
\hline Autumn & 0.09 & & & $0.37^{*}$ & & \\
\hline \multicolumn{7}{|c|}{44 yr (1958-2001) } \\
\hline Sinter & 0.27 & 0.27 & 0.26 & 0.39 & 0.40 & 0.38 \\
\hline Spring & 0.13 & 0.12 & 0.08 & $0.75^{*}$ & $0.69^{*}$ & $0.74^{*}$ \\
\hline Summer & 0.08 & 0.05 & -0.13 & $0.52^{*}$ & $0.48^{*}$ & $0.45^{*}$ \\
\hline Autumn & -0.16 & -0.14 & -0.24 & 0.21 & 0.26 & 0.13 \\
\hline \multicolumn{7}{|c|}{33 yr (1969-2001) } \\
\hline Winter & 0.66 & 0.68 & 0.70 & 0.02 & 0.14 & 0.03 \\
\hline Spring & 0.58 & 0.60 & 0.49 & $0.95^{*}$ & $0.99^{*}$ & $1.00^{*}$ \\
\hline Summer & $0.66^{*}$ & $0.67^{*}$ & $0.54^{*}$ & $0.74^{*}$ & $0.73^{*}$ & $0.88^{*}$ \\
\hline Autumn & 0.08 & 0.09 & 0.04 & 0.28 & 0.29 & 0.22 \\
\hline \multicolumn{7}{|c|}{22 yr (1980-2001) } \\
\hline Winter & 0.70 & 0.65 & 0.62 & -1.30 & -1.30 & -1.37 \\
\hline Spring & $1.38^{*}$ & $1.44^{*}$ & $1.06^{*}$ & $1.38^{*}$ & $1.57^{*}$ & $1.30^{*}$ \\
\hline Summer & $1.35^{*}$ & $1.37^{*}$ & $1.28^{*}$ & $1.27^{*}$ & $1.29^{*}$ & $1.57^{*}$ \\
\hline Autumn & 0.32 & 0.32 & 0.30 & 0.21 & 0.24 & 0.28 \\
\hline
\end{tabular}



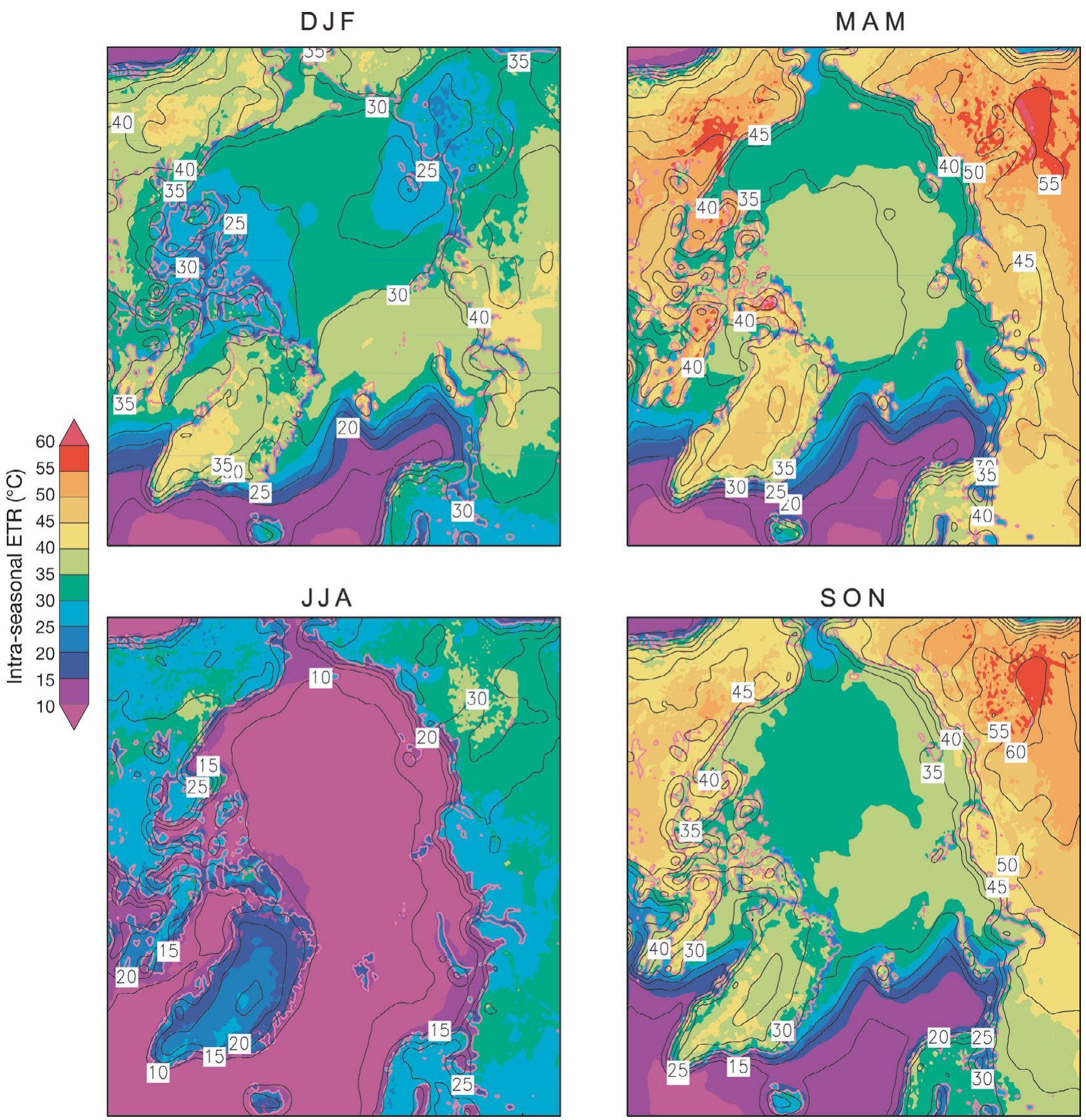

Fig. 5. Seasonal patterns (letters above panels: months) of intra-seasonal extreme temperature range $\left({ }^{\circ} \mathrm{C}\right), 1958$ to 2001 , based on the HIRHAM simulation (color) and ERA40 data (black isolines; contour interval is $5^{\circ} \mathrm{C}$ ). The corresponding comparative measures are given in Table 3. Magenta lines:coastline

\subsection{Variability of the intra-seasonal ETR and its change}

The intra-seasonal ETR is a useful measure of the temperature range for each season (Frich et al. 2002, Alexander et al. 2006). The mean ETR patterns across the Arctic are shown in Fig. 5. The highest magnitudes of ETR ( 40 to $60^{\circ} \mathrm{C}$ ) are found over land in the transition seasons, and the lowest ETR (2 to $10^{\circ} \mathrm{C}$ ) occurs over open oceans and melting summer sea ice. Siberia and Alaska, with a more continental climate, are characterized by a large seasonal variation of ETR, as opposed to 
maritime regions (such as northern Europe and western Russia), which have a lower ETR for all seasons. The mean ETR pattern and their seasonality were in good agreement between HIRHAM and ERA40. Table 3 lists the comparative measures in detail, patcor $>0.8$ and RMSE $\sim 4^{\circ} \mathrm{C}$. Clearly, HIRHAM displayed regional-scale patterns, particularly over mountainous and coastal areas, which were not resolved in the coarser-resolution ERA40.

The ETR patterns have undergone important seasonal changes with time (Fig. 6). The figure illustrates the ETR changes within the second half of the 20th century by comparing the two 22 yr time periods 1980 to 2001 versus 1958 to 1979 . Note that the sign of the ETR inter-period difference is not directly indicative of a warming or cooling. We found a statistically significant decrease in the ETR by 2 to $7^{\circ} \mathrm{C}$ in the second period over the northern North Atlantic (Greenland Sea, Fram Strait, Kara Sea) in winter and the transition seasons. These are the same regions characterized by a decreased ITV associated with their conversion from intermittent ice-covered areas in the former period towards more ice-free areas in the latter period. Over the ice-free ocean, the minimum temperature cannot be lower than ca. $-1.8^{\circ} \mathrm{C}$ (otherwise the water would freeze); therefore the ETR is small, while over the icecovered ocean where ice isolates the air from the warmer water, the minimum temperature can be far lower, resulting in a larger ETR.

Another striking and statistically significant change is the decrease of ETR by 2 to $5^{\circ} \mathrm{C}$ over the East Siberian Sea and land in winter. While this decrease over land follows the decrease in ITV, the ETR decrease over the ocean is associated with an increase in ITV. The latter expresses the change towards a broader temperature distribution. In contrast, a significant ETR increase by 1 to $4^{\circ} \mathrm{C}$ was calculated by HIRHAM over the central Arctic Ocean in summer. ERA40 showed this increase in ETR as well, but it was much less pronounced (only 1 to $2^{\circ} \mathrm{C}$ ) and mostly not significant. As the maximum temperature in summer is constrained by melting ice, this ETR increase in the second period is associated with decreasing minimum temperature at the end of the summer due to an earlier cooling. This is supported by the negative trend and inter-period difference in the minimum temperature over the Arctic Ocean in summer (not shown).

Over land, we found both a decrease and an increase in the ETR, depending on the season and region. A pronounced and significant increase by 2 to $4^{\circ} \mathrm{C}$ was calculated over the east Russian Arctic in winter, while a decrease was detected in the western part of the Russian Arctic, Alaska, and the Canadian archipelago. The high-resolution HIRHAM simulation revealed that changes in ETR are influenced by regional properties, such as altitude and distance from the coast. Considering annual values, climate change studies have found that the intra-annual ETR decrease over Arctic land in future climate projections occurs because changes in minimum temperature are larger than those in maximum temperature (e.g. Uchiyama et al. 2006).

The comparative measures in Table 3 show that the seasonal patterns of the inter-period ETR changes were similar in HIRHAM and ERA40; the pattern correlation was high (patcor $=0.6$ to 0.7 ). The exception is summer, where ERA40 disagreed with the prevailing increase of ETR over the Arctic Ocean calculated by HIRHAM, such that the correlation between both was only 0.4 .

The regional analysis of ETR over Russian Arctic land (Fig. 7) also shows inconsistently observed changes as already seen in the spatial patterns. The observed ETR time series show both a decrease and an increase, depending on season and region, and most of the trends are small in magnitude and not statistically significant. The only significant ETR trend over the $51 \mathrm{yr}$ record was calculated as a decline of $-0.3^{\circ} \mathrm{C}$ decade $^{-1}$ for GSOD east in summer (Table 4). This decrease is again not due to a general shift in the temperature distribution. A significant increase in daily minimum (maximum) temperature by $0.5^{\circ} \mathrm{C}\left(0.6^{\circ} \mathrm{C}\right)$ decade $^{-1}$ was found for GSOD east in summer over 1958 to 2008; hence if the change in ETR was due to the shift in the mean minimum and maximum temperature, it would have to increase. Rather, the decrease in ETR is caused by less extreme ends of the tempera-

Table 3. Comparison of intra-seasonal extreme temperature range (ETR) patterns of the HIRHAM simulation and ERA40 data. Shown are the root mean square error (RMSE, ${ }^{\circ} \mathrm{C}$ ), mean bias 'HIRHAM minus ERA40' (bias, ${ }^{\circ} \mathrm{C}$ ), and pattern correlation coefficient (patcor) for the seasonal mean and standard deviation (SD) of 1958 to 2001 and the difference '1980-2001 minus 1958-1979'

\begin{tabular}{|c|c|c|c|c|c|c|c|c|c|c|c|c|}
\hline & \multicolumn{3}{|c|}{ Seasonal mean } & \multicolumn{3}{|c|}{ Difference of seasonal mean } & \multicolumn{3}{|c|}{ Seasonal SD } & \multicolumn{3}{|c|}{ Difference of SD } \\
\hline & RMSE & bias & patcor & RMSE & bias & patcor & RMSE & bias & patcor & RMSE & bias & patcor \\
\hline Winter & 4.51 & -0.07 & 0.83 & 1.37 & 0.01 & 0.74 & 0.85 & -0.10 & 0.68 & 0.94 & -0.02 & 0.57 \\
\hline Spring & 4.64 & 0.14 & 0.92 & 1.32 & -0.29 & 0.60 & 0.76 & 0.22 & 0.83 & 0.89 & 0.24 & 0.56 \\
\hline Summer & 4.21 & -0.68 & 0.91 & 1.14 & 0.46 & 0.38 & 0.72 & -0.13 & 0.62 & 0.59 & 0.13 & 0.30 \\
\hline Autumn & 4.25 & 0.78 & 0.93 & 1.25 & 0.04 & 0.61 & 0.79 & 0.18 & 0.85 & 0.90 & -0.21 & 0.57 \\
\hline
\end{tabular}



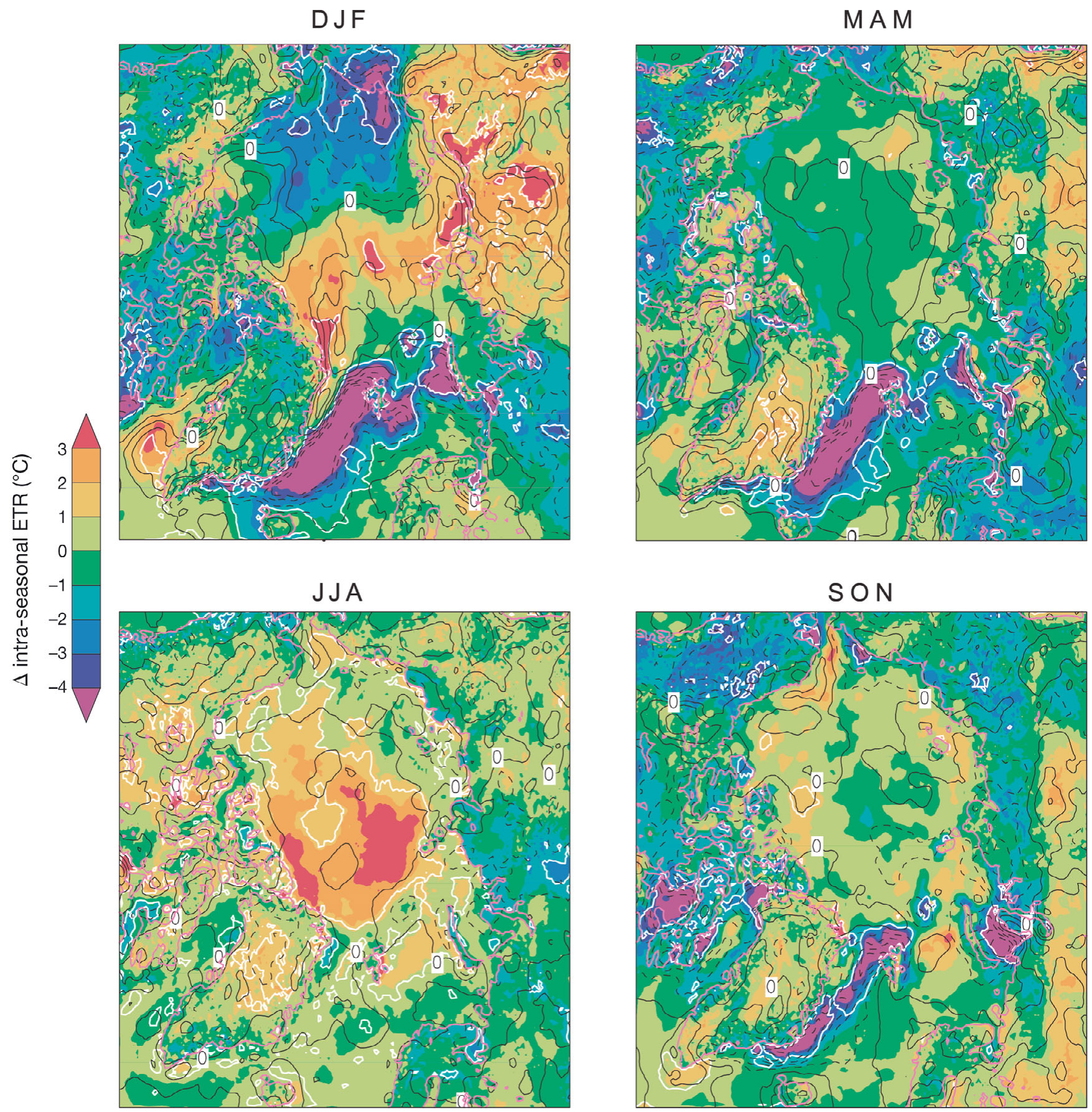

Fig. 6. Seasonal patterns (letters above panels: months) of the difference '1980-2001 minus 1958-1979' of the intra-seasonal extreme temperature range $\left({ }^{\circ} \mathrm{C}\right.$ ), based on the HIRHAM simulation (color) and ERA40 data (black isolines; contour interval is $1{ }^{\circ} \mathrm{C}$; positive [negative] differences are plotted as solid [dashed] isolines). White isolines: significant HIRHAM differences at the $95 \%$ level. The corresponding comparative measures are given in Table 3. Magenta lines: coastline

ture distribution. Furthermore, the station observations, ERA40, and HIRHAM agreed for GSOD east in spring on a strong positive ETR trend of ca. $2^{\circ} \mathrm{C}$ decade $^{-1}$ in the last $22 \mathrm{yr}$ (1980 to 2001). This is in agreement with findings of an earlier spring snow melt in recent decades and thus increased heating and warmer spring temperature (e.g. Euskirchen et al. 2007). Another interesting pattern appeared for GSOD west in autumn. This was the only case where positive ETR trends were dominant in all time slices, and where 
ETR variability $\left({ }^{\circ} \mathrm{C}\right)$

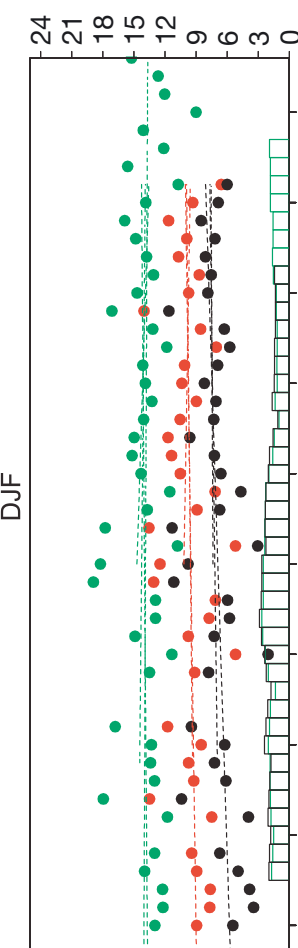

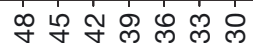

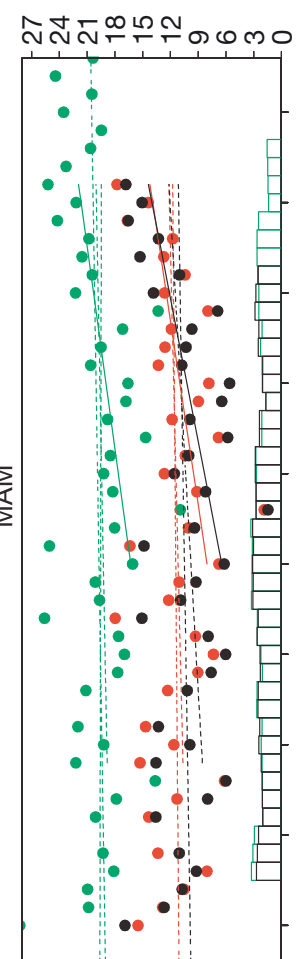

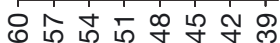

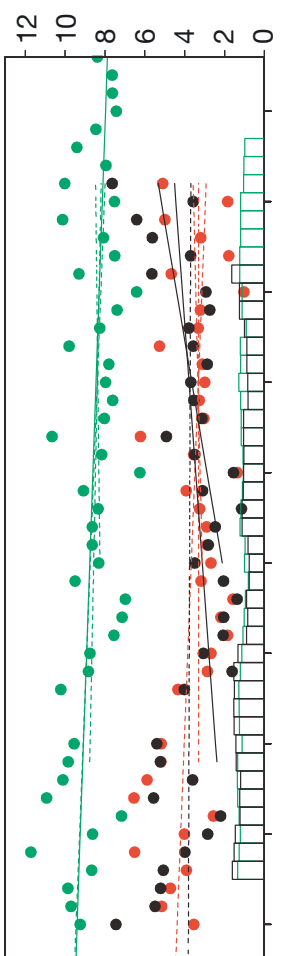

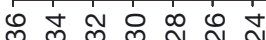

$\operatorname{ETR}\left({ }^{\circ} \mathrm{C}\right)$

ETR variability $\left({ }^{\circ} \mathrm{C}\right)$

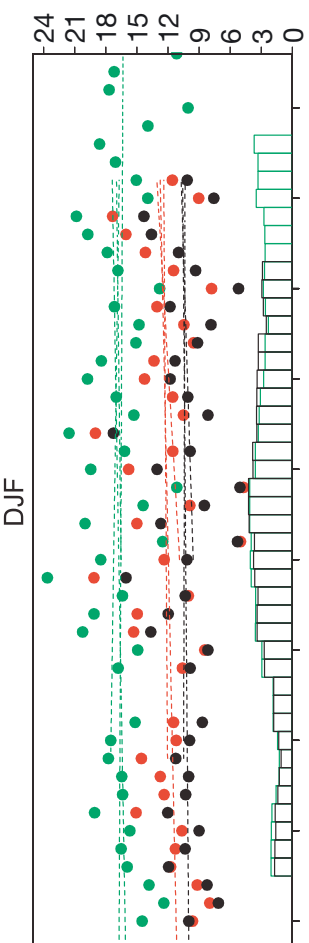

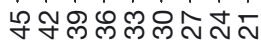

Nomomo

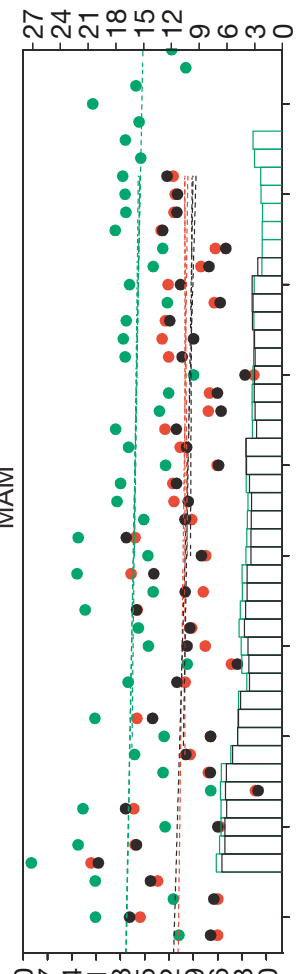

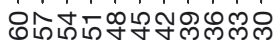

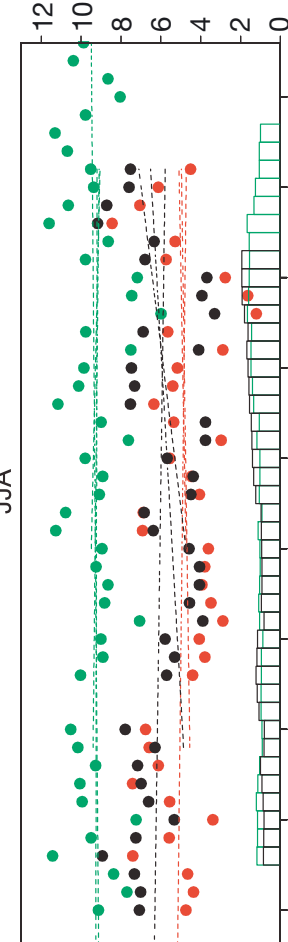

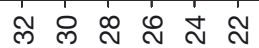
$\operatorname{ETR}\left({ }^{\circ} \mathrm{C}\right)$

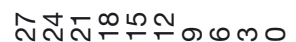

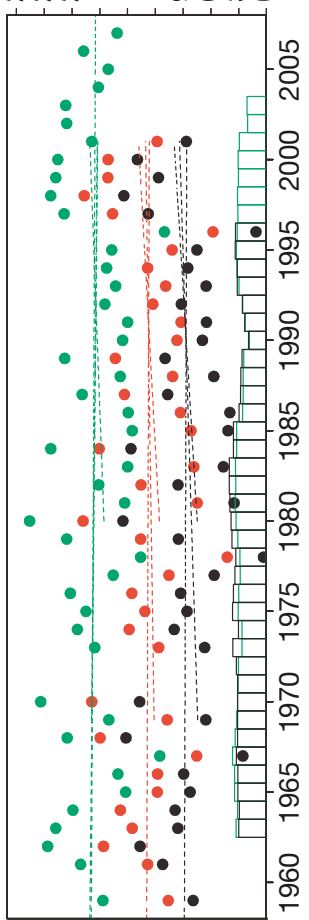

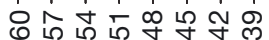

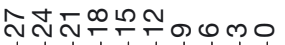

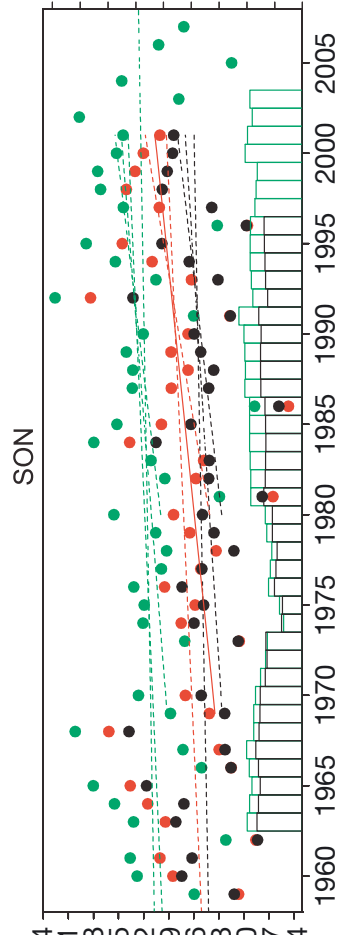

可.

पे

च्च

명

동 의

뭉 뭉

ब)

중

음

욤

莺灵

色

ㅇํ며

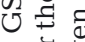

훙

. 0

嗼

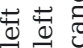

w

$3 \div$ क

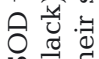

Uै

등 :

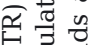

凷署

$\Phi \sum 0$

可

牙宁

幽跑

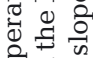

묘 믕

\&

至

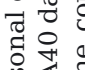

范

니

㐘昆

氙

융 중

동

व

部

은?

몽

ซี ญ

1. 0

辛吉

ब्र

人

完呑 
Table 4. Seasonal trends of intra-seasonal extreme temperature range $\left({ }^{\circ} \mathrm{C}\right.$ decade $^{-1}$ ). The numbers are given for station-based (GSOD) and ERA40 data, and for the HIRHAM simulation. ${ }^{*} \mathrm{p}<0.05$

\begin{tabular}{|c|c|c|c|c|c|c|}
\hline & \multicolumn{3}{|c|}{$\longrightarrow$ GSOD west } & \multicolumn{3}{|c|}{ GSOD east } \\
\hline & GSOD & ERA40 & HIRHAM & GSOD & ERA40 & HIRHAM \\
\hline \multicolumn{7}{|c|}{51 yr (1958-2008) } \\
\hline Winter & -0.08 & & & -0.07 & & \\
\hline Spring & -0.43 & & & 0.25 & & \\
\hline Summer & 0.07 & & & $-0.32^{*}$ & & \\
\hline Autumn & 0.38 & & & -0.08 & & \\
\hline \multicolumn{7}{|c|}{44 yr (1958-2001) } \\
\hline Winter & 0.33 & 0.40 & 0.15 & 0.12 & 0.22 & 0.49 \\
\hline Spring & -0.39 & -0.28 & -0.64 & -0.03 & 0.12 & 0.25 \\
\hline Summer & -0.01 & -0.09 & -0.12 & -0.35 & -0.35 & -0.08 \\
\hline Autumn & 0.85 & 0.97 & 0.41 & -0.16 & -0.05 & -0.05 \\
\hline \multicolumn{7}{|c|}{33 yr (1969-2001) } \\
\hline Winter & -0.28 & 0.12 & -0.05 & -0.15 & 0.16 & 0.20 \\
\hline Spring & -0.25 & 0.00 & -0.38 & 0.29 & 0.37 & 0.88 \\
\hline Summer & -0.09 & 0.12 & 0.48 & -0.18 & 0.00 & $0.66^{*}$ \\
\hline Autumn & 1.72 & $2.24^{*}$ & 1.38 & -0.16 & 0.02 & 0.05 \\
\hline \multicolumn{7}{|c|}{22 yr (1980-2001) } \\
\hline Winter & 0.22 & 1.13 & 0.60 & -0.48 & -0.26 & 0.08 \\
\hline Spring & -0.31 & 0.17 & -0.09 & $2.11^{*}$ & $2.31^{*}$ & $2.97^{*}$ \\
\hline Summer & -0.19 & 0.16 & 1.04 & 0.10 & 0.22 & 0.15 \\
\hline Autumn & 2.60 & 3.66 & 2.51 & 0.60 & 0.88 & 0.97 \\
\hline
\end{tabular}

the trend magnitude increased towards recent years

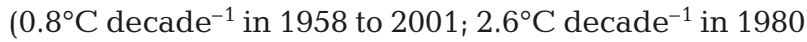
to 2001). The station observations, ERA40, and HIRHAM agreed on this behavior, which can be attributed to warmer September temperatures, which also prolong the growing season. At the beginning of the season, high daily maximum temperatures similar to those expected during summer are more often recorded in recent times; however, by the end of the season, the daily minimum temperatures decrease to winter levels as usual, causing an increased ETR with time. This is in agreement with findings that the nearsurface warming in autumn has increased over time, associated with strong upward heat fluxes to the atmosphere from anomalous areas of open water (Ogi \& Wallace 2007, Barrett \& Serreze 2008) as well as with the finding of later autumn Arctic Ocean freeze-up (Martin \& Munoz 1997).

The ETR also showed a pronounced interannual variability with a distinct seasonality (Fig. 8). A maximum interannual ETR variability of 4 to $7^{\circ} \mathrm{C}$ was found (1) over land in winter and the transition seasons due to strong interannual variability affecting the year-to-year hottest/coldest daily temperatures and (2) along the sea ice edges in winter and the transition seasons due to strong year-to-year variability of daily maximum temperatures due to alternate exposure of those regions to open water or ice. A minimum ETR variability of 0.5 to $2^{\circ} \mathrm{C}$ occurred (1) over land in sum- mer associated with the low interdiurnal temperature variability and its low year-to-year changes, (2) generally over open oceans due to the moderate year-to-year near-surface temperature changes, and (3) over melting sea ice due to the confinement of temperatures to the melting point. Over the Arctic Ocean in winter, the interannual ETR variability was as high as over land (4 to $6^{\circ} \mathrm{C}$ ), while in all other seasons, this ocean variability was ca. $2.5^{\circ} \mathrm{C}$ lower than over land. This is due to the fact that the minimum and maximum temperatures over sea ice in winter are not restricted by melting sea ice as in the other seasons. HIRHAM reproduced the spatial patterns and seasonality given by ERA40 in all seasons, and clearly, HIRHAM added regional-scale details particularly over mountainous regions due to its higher spatial resolution. The comparative measures in Table 3 demonstrate the similarity of the ERA40 and HIRHAM patterns; the pattern correlation was high (e.g. patcor $>0.8$ in spring and autumn) and the mean biases were small (e.g. RMSE $<0.8^{\circ} \mathrm{C}$ ).

The regional time series of the ETR (Fig. 7) also highlight its large interannual variability, and the regional differences become more obvious. The observed maximum limits of variation of ETR (difference between the maximum and minimum ETR within the whole 51 yr period) in winter, and the transition seasons in GSOD west, were about 2 times larger than in GSOD east. Both in GSOD west and east, this variation had its maximum in the transition seasons $\left(25^{\circ} \mathrm{C}\right.$ in the west, and $12^{\circ} \mathrm{C}$ in the east). The magnitude of ETR during summer was equally small for both GSOD west and east (on average on the order of $30^{\circ} \mathrm{C}$ ) and had small maximum limits of variation of only about $5.5^{\circ} \mathrm{C}$. Fig. 7 further demonstrates that the HIRHAM-calculated SDs of ETR (green bars in the figure) are in agreement with those derived from the station data (black bars), indicating that the interannual ETR variability and its temporal changes are well captured by the model. A strong decadalscale variability in the ETR SD is shown. However, both HIRHAM and ERA40 systematically underestimated the observed absolute ETR values in all seasons. This may partly be explained by a general overestimation of the mean minimum temperatures in winter and spring and underestimation of the mean maximum temperature in summer and autumn (not shown). 

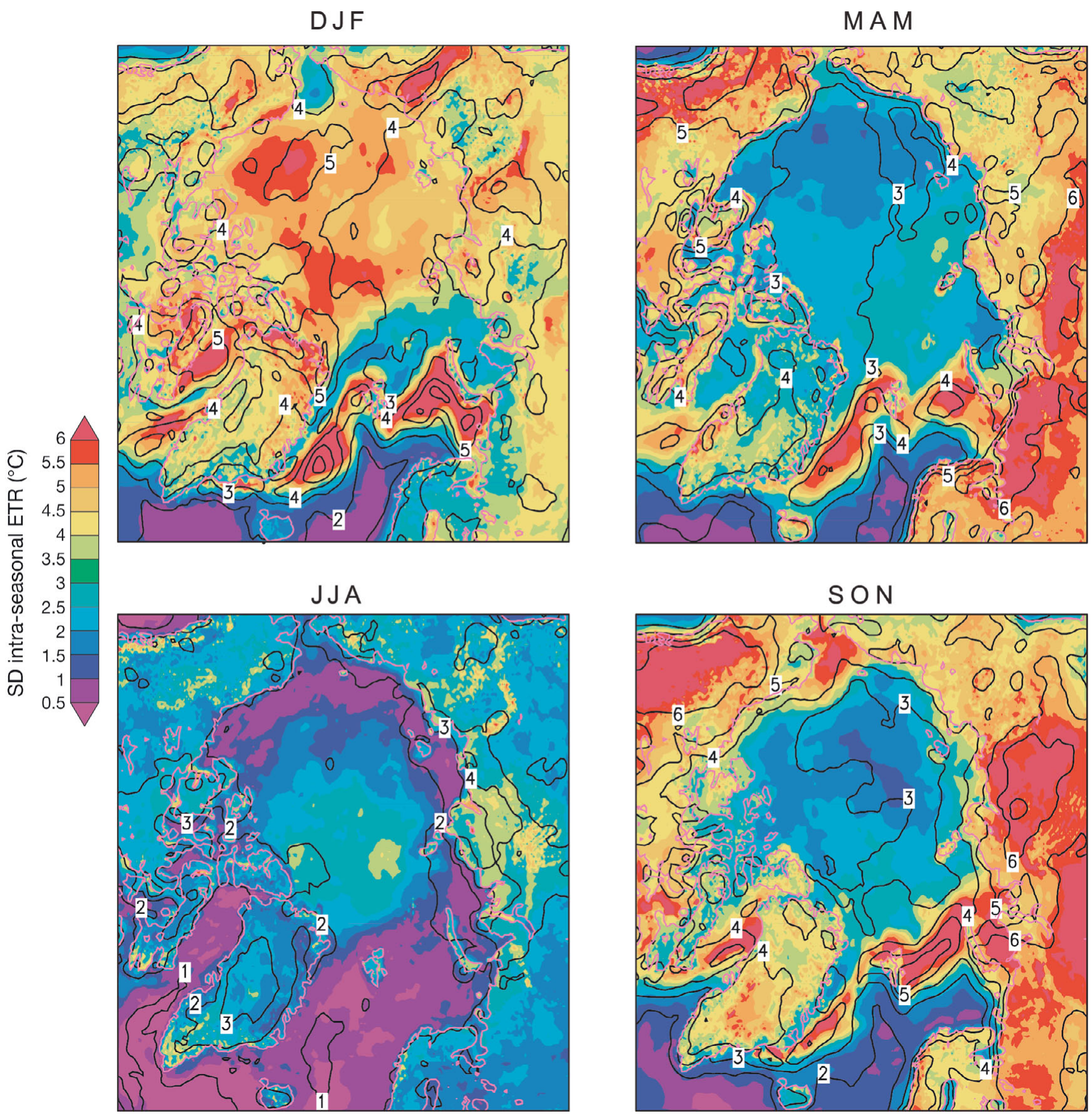

Fig. 8. Seasonal patterns (letters above panels: months) of standard deviation of intra-seasonal extreme temperature range $\left({ }^{\circ} \mathrm{C}\right), 1958$ to 2001, based on the HIRHAM simulation (color) and ERA40 data (black isolines; contour interval is $0.5^{\circ} \mathrm{C}$ ). The corresponding comparative measures are given in Table 3. Magenta lines: coastline

Accordingly, changes in the ETR interannual variability are expected if one considers the inter-period differences (Figs. 9 \& 10). The figures point to strong regional as well as seasonally different changes. The inter-period change in ETR variability showed substan- tial spatial differences across the pan-Arctic. It showed both a decrease and increase, depending on the region and season, which reflects the different changes in the variability of daily maximum/minimum temperature. The significant decrease in the ETR variability along 

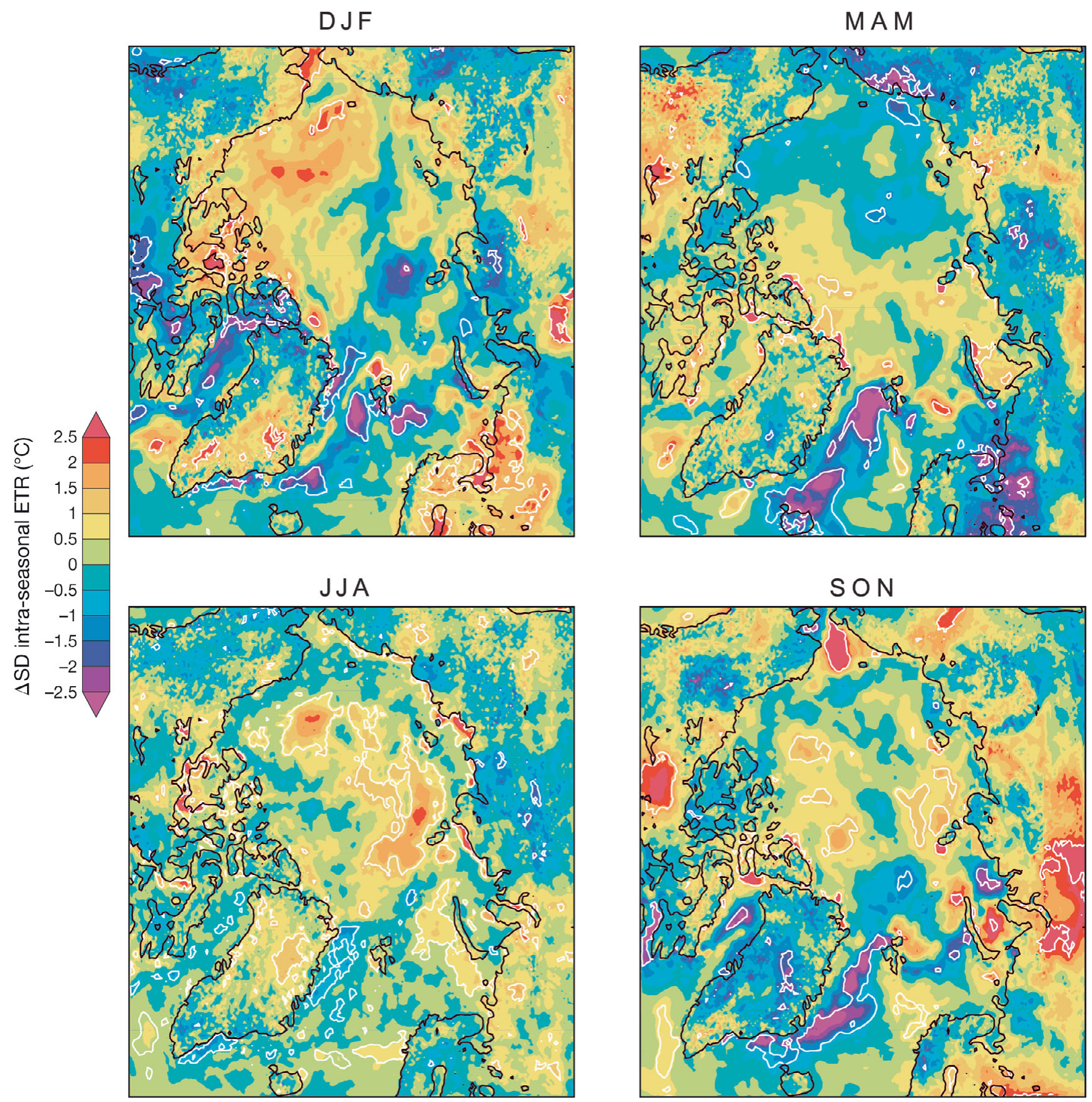

Fig. 9. Seasonal patterns (letters above panels: months) of the difference '1980-2001 minus 1958-1979' of the standard deviation of the intra-seasonal extreme temperature range $\left({ }^{\circ} \mathrm{C}\right)$, based on the HIRHAM simulation. White isolines: significant differences at the $95 \%$ level. Black lines: coastline

the sea ice edges in winter and the transition seasons agrees with the transition of these regions to more open water in the second period. Table 3 quantifies the moderate agreement between ERA40 and HIRHAM.

Measures other than the ETR that can represent the amplitude of the intraseasonal variability focus on the tails of the distribution, for instance the 95 to $5 \%$ quantile range within a season. We calculated the seasonal spatial patterns of this quantile range of $2 \mathrm{~m}$ air temperature and confirm that the ETR results presented here are representative of the intraseasonal variability and its change. 

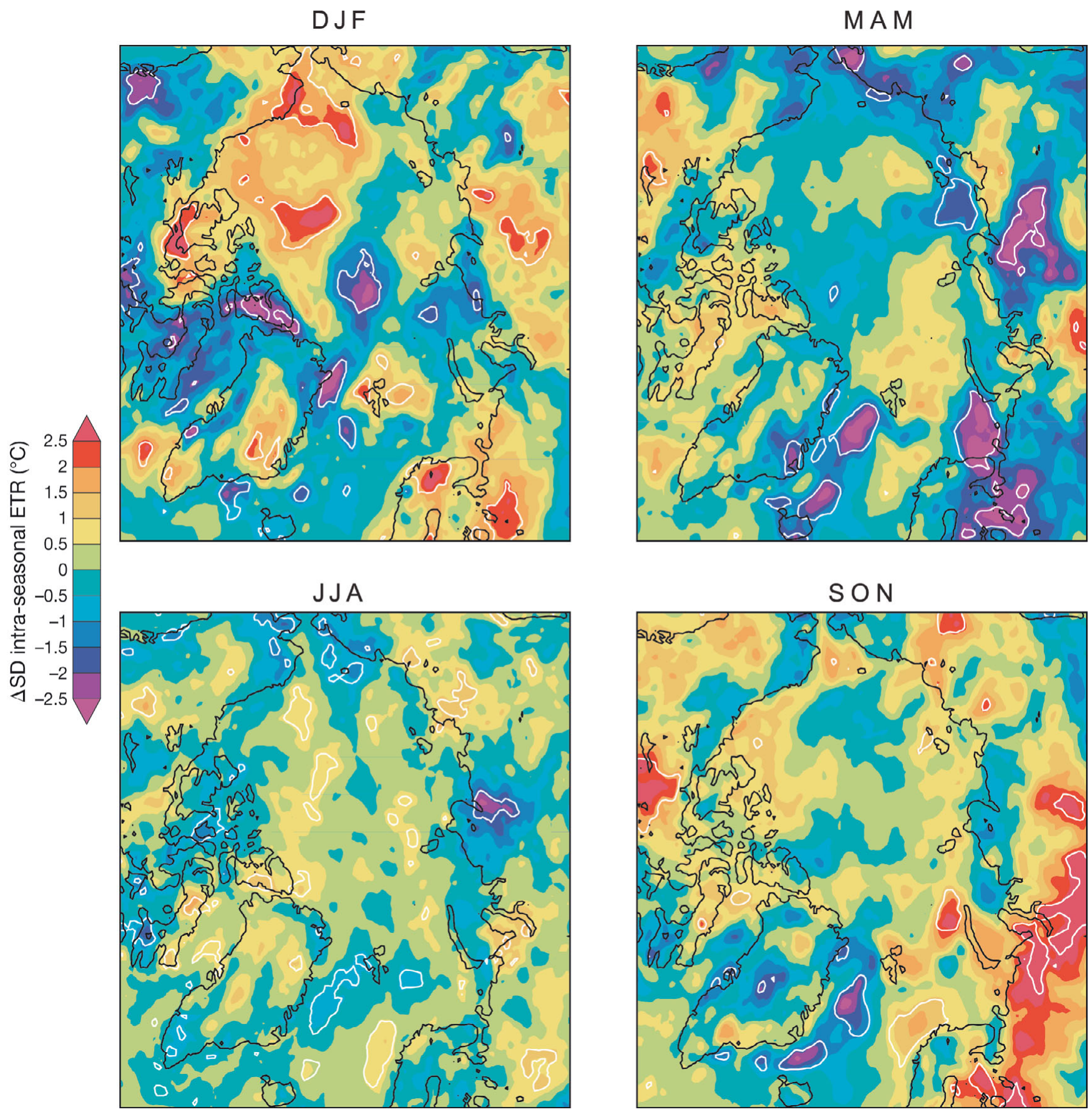

Fig. 10. Seasonal patterns (letters above panels: months) of the difference '1980-2001 minus 1958-1979' of the standard deviation of the intra-seasonal extreme temperature range $\left({ }^{\circ} \mathrm{C}\right)$, based on ERA40 data. White isolines: significant differences at the $95 \%$ level. Black lines: coastline

\section{SUMMARY AND CONCLUSIONS}

Not unexpectedly, we found some differences in the temperature magnitudes between station data and the gridded data of ERA40 and HIRHAM, as the models do not fully represent the topography and local effects that influence the station data. The primary disagreements appeared to be associated with the coastal resolution and the spatial averaging inherent in grid-cell means, wherein the ERA40 data have a 4 -fold coarser resolution than the HIRHAM simulations. Obviously, the reanalyses have the advantage that they assimilate 
many in situ measurements and satellite products. However, some discrepancies between ERA40 and station observations, particularly in the extreme temperature range, are emphasized in the paper.

However, the general shape and magnitude of the Arctic temperature variability and change, both of seasonal temperature and intra-seasonal ETR, were well reproduced by both the models and the reanalysis. This general agreement suggests that HIRHAM can be used to extend the analysis to 21 st century projections to assess possible changes in temperature variability in future decades. Another implication is that the model output is useful for climate impact studies, e.g. to drive sea ice, permafrost, and ecosystem models.

Most trends in the observed seasonal temperature and intra-seasonal ETR were not statistically significant. The trends in seasonal temperatures were positive everywhere, but only significant for GSOD east (0.4 to $1.4^{\circ} \mathrm{C}$ decade $^{-1}$, depending on season and time slice), while the ETR trends were of mixed sign and were also only significant for GSOD east $\left(2^{\circ} \mathrm{C}\right.$ decade $\mathrm{d}^{-1}$ in spring for 1980 to $2001,-0.3^{\circ} \mathrm{C}_{\text {decade }}$ de $^{-1}$ in summer for 1958 to 2008). The large variability of the Arctic temperature and its extremes, which is inherent in the analysis period, demonstrates that natural variability is an important factor in the Arctic climate. The interannual variability of both temperature measures in turn shows a pronounced decadal variability and considerable regional and seasonal differences.

Acknowledgements. This research was funded by the European Union project CARBO-North. We thank I. Hebestadt for programming support and the anonymous reviewers whose comments helped to improve the manuscript.

\section{LITERATURE CITED}

Alexander LV, Zhang X, Peterson TC, Caesar J and others (2006) Global observed changes in daily climate extremes of temperature and precipitation. J Geophys Res 111: D05109. doi:10.1029/2005JD006290

Barrett AP, Serreze MC (2008) Arctic atmospheric circulation and surface air temperature anomalies: Are the rules changing? Proc Am Geophys Union, Fall Meeting, C53A-07

> Chapman WL, Walsh JE (2007) Simulations of Arctic temperature and pressure by global coupled models. J Clim 20: 609-632

Chylek P, Folland CK, Lesins G, Dubey MK, Wang M (2009) Arctic air temperature change amplification and the Atlantic Multidecadal Oscillation. Geophys Res Lett 36: L14801, doi:10.1029/2009GL038777

Dethloff K, Rinke A, Lehmann R, Christensen JH, Botzet M, Machenhauer B (1996) Regional climate model of the Arctic atmosphere. J Geophys Res 101:23401-23422

Euskirchen ES, McGuire AD, Chapin FS III (2007) Energy feedbacks of northern high-latitude ecosystems to the cli- mate system due to reduced snow cover during 20th century warming. Glob Change Biol 13:2425-2438

Frich P, Alexander LV, Della-Marta P, Gleason B, Haylock M, Klein Tank AMG, Peterson T (2002) Observed coherent changes in climatic extremes during the second half of the twentieth century. Clim Res 19:193-212

$>$ Jones PD, Moberg A (2003) Hemispheric and large-scale surface air temperature variations: an extensive revision and an update to 2001. J Clim 16:206-223

Kiktev D, Sexton DMH, Alexander L, Folland CK (2003) Comparison of modeled and observed trends in indices of daily climate extremes. J Clim 16:3560-3571

Martin S, Munoz EA (1997) Properties of the Arctic 2-meter air temperature field for 1979 to the present derived from a new gridded dataset. J Clim 10:1428-1440

> Matthes H, Rinke A, Dethloff K (2009) Variability of observed temperature-derived climate indices in the Arctic. Glob Planet Change 69:214-224

Ogi A, Wallace JM (2007) Summer minimum Arctic sea ice extent and the associated summer atmospheric circulation. Geophys Res Lett 34:L12705, doi:10.1029/2007GL029897

> Overland JE, Spillane MC, Percival DB, Wang M, Mofjeld HO (2004) Seasonal and regional variation of pan-Arctic surface air temperature over the instrumental record. J Clim 17:3263-3282

Przybylak R (2002) Changes in seasonal and annual high-frequency air temperature variability in the Arctic from 19511990. Int J Climatol 22:1017-1032

> Rinke A, Dethloff K (2008) Simulated circum-Arctic climate changes by the end of the 21st century. Glob Planet Change 62:173-186

> Rinke A, Kuhry P, Dethloff K (2008) Importance of a soil organic layer for Arctic climate: a sensitivity study with an Arctic RCM. Geophys Res Lett 35:L13709, doi:10.1029/ 2008GL034052

> Rinke A, Melsheimer C, Dethloff K, Heygster G (2009) Arctic total water vapor: comparison of regional climate simulations with observations, and simulated decadal trends. J Hydrometeorol 10:113-129

Roeckner E, Arpe K, Bengtsson L, Christoph M and others (1996) The atmospheric general circulation model ECHAM-4: model description and simulation of presentday climate. Max Planck Inst Meteorol Rep 218

Saha SK, Rinke A, Dethloff K, Kuhry P (2006) Influence of a complex land surface scheme on Arctic climate simulations. J Geophys Res 111:D22104, doi:10.1029/2006JD 007188

> Serreze MC, Francis JA (2006) The Arctic amplification debate. Clim Change 76:241-264

Serreze MC, Box JE, Barry RG, Walsh JE (1993) Characteristics of Arctic synoptic activity, 1952-1989. Meteorol Atmos Phys 51:147-164

> Sorteberg A, Kvingedal B (2006) Atmospheric forcing on the Barents Sea winter ice extent. J Clim 19:4772-4784

> Uchiyama T, Mizuta R, Kamiguchi K, Kitoh A, Noda A (2006) Changes in temperature- based extremes indices due to global warming projected by a global $20-\mathrm{km}$-mesh atmospheric model. Sci Online Lett Atmos 2:68-71

> Uppala SM, Kallberg PW, Simmons AJ, Andrae U and others (2005) The ERA-40 re-analysis. QJR Meteorol Soc 131: 2961-3012

Zhang X, Walsh JE, Zhang J, Bhatt US, Ikeda M (2004) Climatology and interannual variability of Arctic cyclone activity, 1948-2002. J Clim 17:2300-2317

Submitted: October 14, 2009; Accepted: February 19, 2010

Proofs received from author(s): April 9, 2010
Editorial responsibility: Mikhail Semenov,

Harpenden, UK 